\title{
A correlation between Bogue's equations and Taylor's procedure for the evaluation of crystalline phases in special class Portland oilwell cement clinker
}

\section{(Correlação entre as equações de Bogue e o procedimento de Taylor na avaliação das fases cristalinas de um cimento Portland especial para cimentação de poços de petróleo)}

\author{
U. T. Bezerra', A. E. Martinelli', D. M. A. Melo' , M. A. F. Melo', F. M. Lima ${ }^{3}$ \\ ${ }^{I}$ Federal Centre of Tech. Education of Paraiba, CEFET-PB, Av. $1^{\circ}$ Maio 720, Jaguaribe, J. Pessoa, PB 58015-430 \\ ${ }^{2}$ Federal University of Rio Grande do Norte - UFRN, Av. Sen. Salgado Filho 3000, \\ Campus Lagoa Nova, Natal, RN 59078-970 \\ ${ }^{3}$ Petróleo Brasileiro S.A. - Petrobrás, Vitória, ES \\ dartarios@yahoo.com.br,aemart@uol.com.br,dmelo@matrix.com.br, \\ marcosmelo@matrix.com.br,flank@petrobras.com.br
}

\begin{abstract}
The crystalline composition of Portland cement clinker is commonly established by Bogue's equations, which are based on a series of assumptions that seldom apply to oilwell cements. This is probably due to the presence of additional oxides and phase reconversion upon cooling of the clinker from the calcination temperature. Important differences are therefore observed between the numerical values yielded by the mathematical equations and image analysis quantification. In this study, the concentration of crystalline phases in oilwell cement was determined using Taylor's procedure, which consists in a system of linear equations corresponding to each one of the four main clinker phases. The results revealed an adequate relationship between this method and phase quantification by optical micrography, especially concerning the contents of aluminate and ferrite.
\end{abstract}

Keywords: characterization, crystal structure, clinker, oil well cement.

Resumo

A composição cristalina das fases do clínquer de cimento Portland é comumente avaliada pelas equações de Bogue, que se baseiam em alguns princípios que podem ser aplicados aos cimentos para cimentação de poços de petróleo. Isto se deve provavelmente à presença de diversos óxidos e reconversões de fase durante o resfriamento do clínquer levado à altas temperaturas. Entretanto, diferenças importantes são observadas entre os valores numéricos obtidos nas equações e a quantificação de fases por imagem. Neste estudo, a quantidade das fases cristalinas do clínquer de um cimento especial para poço de petróleo foi determinada empregando o procedimento de Taylor, que consiste na resolução de um sistema de equações lineares correspondente a cada uma das quatro principais fases do clínquer. Os resultados revelam uma adequada inter-relação entre este método e a quantificação das fases por microscopia ótica, principalmente no que se refere à determinação dos teores de alumínio e ferro.

Palavras-chave: caracterização, estrutura cristalina, clínquer, cimento para poço de petróleo.

\section{INTRODUCTION}

Portland cement is manufactured from mixtures of limestone, clay minerals and other compounds added in minor concentrations to adjust specific properties of the material to particular applications. After firing, the anhydrous cement clinker depicts four partially crystalline phases, i.e., alite, belite, celite and ferrite. Calcium sulfate is then added to the clinker to control its setting time [1-3]. Some of the main characteristics of these phases are listed in Table I.

Although the thermodynamic reactions involved in the production of the different classes of Portland cement affect the final physical and mechanical properties of the material, differences in the Blaine cement fineness and relative contents of the main clinker minerals are mainly responsible for that. Coarse cements with low specific surface usually take longer times to set due to the sluggish hydration kinetics. On the other hand, high contents of $\mathrm{C}_{3} \mathrm{~A}$ speed up the reactions resulting in relatively short setting times. The properties of Portland cement are mainly determined not by the presence of different compounds but by the relative contents of the four main clinker constituents and the fineness of the cement. From the main oxide components used in the production of Portland cement, i.e., lime, silica, alumina and ferrite, it 
Table I - Main crystalline phases in Portland cement. [Tabela I - Principais fases cristalinas do cimento Portland.]

\begin{tabular}{cccc}
\hline Crystalline Phase & Composition & $\begin{array}{c}\text { Abbreviated } \\
\text { notation }\end{array}$ & $\begin{array}{c}\text { Specific gravity } \\
\left(\mathrm{kg} / \mathrm{m}^{3}\right)\end{array}$ \\
\hline Tricalcium silicate & $3 \mathrm{CaO} \mathrm{SiO}_{2}$ & $\mathrm{C}_{3} \mathrm{~S}$ (alite) & 3210 \\
Dicalcium silicate & $2 \mathrm{CaO} \mathrm{SiO}_{2}$ & $\mathrm{C}_{2} \mathrm{~S}$ (belite) & 3280 \\
Tricalcium aluminate & $3 \mathrm{CaO} \mathrm{Al} \mathrm{O}_{3}$ & $\mathrm{C}_{3} \mathrm{~A}$ (celite) & 3030 \\
Tetracalcium ferroaluminate & $4 \mathrm{CaO} \mathrm{Al} \mathrm{O}_{3} \mathrm{Fe}_{2} \mathrm{O}_{3}$ & $\mathrm{C}_{4} \mathrm{AF}$ (ferrite) & 3730 \\
\hline
\end{tabular}

is possible to establish the relative contents of the main clinker products using the traditional Bogue's approach, developed by R. H. Bogue in 1929 and later modified by ASTM C 1356-96 [4]. One of the assumptions of this method is that the clinker is fired at $2000{ }^{\circ} \mathrm{C}$. Moreover, the four main clinker products are in their plain form and there is a stoichiometric relationship between them. Since the cement is not always produced under these conditions, the results obtained solving Bogue's equations deviate from the real composition of the clinker. Different reports [57] have also revealed variations not only on the constants used to multiply the oxide contents but also on the use of the equations itself.

Methods including reflected optical microscopy and image analysis [4], as well as quantitative X-ray diffraction [8-10], offer experimental tools to verify the quality of Bogue's estimates. The quantification of clinker phases by $\mathrm{X}$-ray diffraction has been carried out based on the relative intensity of the diffraction peaks of each phase present in the clinker with respect to pure phase standards. This method is based on the work by Klug and Alexander [8], who established a relationship between the intensity of the peak of a given mineral and its concentration, taking into account its specific gravity and mass absorption coefficient, as well as the X-ray absorption characteristics of the matrix where the mineral is dispersed [8]. Their basic methodology was further improved resulting in more precise approaches including the internal and external standard methods, the amorphousstandard-addition method, and a standardless approach based on the relative peak height or area of a sample compared with a calibration curve $[8,9]$. Furthermore, clinkers are commonly fired around $1450{ }^{\circ} \mathrm{C}$ and include low-fusing impurities in their compositions, such as $\mathrm{MgO}, \mathrm{Na}_{2} \mathrm{O}, \mathrm{P}_{2} \mathrm{O}_{5}, \mathrm{~K}_{2} \mathrm{O}, \mathrm{SO}_{3}$, and free $\mathrm{CaO}$, among others, as well as the substitution of impurity cations in the crystalline lattices of the clinker phases. The presence of such impurities affects the contents of the four main phases of the clinker reported by Bogue's equations. The most common discrepancies are encountered in the sum of the silicates, i.e., $\mathrm{C}_{3} \mathrm{~S}$ and $\mathrm{C}_{2} \mathrm{~S}$, which is usually $\sim 14 \%$ less than the amount inferred by optical microscopy and quantitative $\mathrm{X}$-ray diffraction, or in the sum of interstitial $\mathrm{C}_{3} \mathrm{~A}$ and $\mathrm{C}_{4} \mathrm{AF}$, which normally exceeds the estimates obtained by the same two techniques. Moreover, lower amounts of free lime and higher amounts of $\mathrm{CaO}$ and $\mathrm{MgO}$ are usually detected by experimental techniques compared to the values obtained by Bogue's equations $[8,9]$. Finally, as the clinker is cooled down some the reactions can be partially reversed $[6,11]$, also limiting the accuracy of Bogue's model. Regardless of their limitations, Bogue's equations are widely used by cement manufacturers. The spreading of the results is taken as inevitable and not as the basis for improvement in quality control. However, this is not the case for oilwell cement. They may contain even higher levels of impurities, and the quality control in clinker production must be quite rigorous. Optical microscopy and quantitative X-ray diffraction are useful tools to accurately determine the contents of the main clinker phases, however, such estimates should be done prior to clinker production. To that end, Yamaguchi, Takagi, Harrisson, Winter and Taylor [6] proposed an accurate method to determine the composition of a clinker based on their original oxides and impurities as the input of a system of linear equations.

Therefore, the objective of the present study was to determine the contents of the four main clinker phases of oilwell Portland cement using Taylor's procedure and compare the results with the estimates obtained from Bogue's equation.

\section{MATERIALS AND METHODS}

Samples of a Special Class Portland Oilwell Cement produced in Northeastern Brazil for onshore oilwells were used. In addition to the clinker used, results from the last 34 batches were also taken into account (Table II).

The specific mass of the cement was determined using a Le Chatelier test. The procedure was repeated four times yielding the results listed in Table III.

\section{RESULTS AND DISCUSSION}

The specific mass of conventional Portland G cement used in oilwells is $\sim 3.400 \mathrm{~kg} / \mathrm{m}^{3}$ [11], i.e., a difference of $\sim 248 \mathrm{~kg} / \mathrm{m}^{3}(\sim 7 \%)$ compared to Special Class cement, as a result of the higher contents of $\mathrm{Fe}_{2} \mathrm{O}_{3}$ of the former. According to API [13], the contents of $\mathrm{C}_{4} \mathrm{AF}$ in Portland G are $~ 12 \%$ [12], whereas the special class cement studied depicted $9.69 \%$. Such difference itself could not explain the reduction in specific mass from 3.400 to $\sim 3.150 \mathrm{~kg} / \mathrm{m}^{3}$. Nevertheless, better estimates of the composition of the special class Portland revealed that the contents of $\mathrm{C}_{4} \mathrm{AF}$ were lower than the values obtained by Bogue's equations, which accounts for the specific mass values lower than $3.400 \mathrm{~kg} / \mathrm{m}^{3}$. These numbers take into account the impurities present in the four 
Table II - Characteristics of the special class portland oilwell cement.

[Tabela II - Características do cimento classe especial para poço de petróleo.]

\begin{tabular}{|c|c|c|c|c|}
\hline \multicolumn{5}{|c|}{ Chemical composition of the 34 batches clinker (\%) } \\
\hline & Minimum & Average & Maximum & Standard deviation \\
\hline Loss on ignition & 0.60 & 1.08 & 2.08 & 0.38 \\
\hline $\mathrm{SiO}_{2}$ & 19.25 & 20.64 & 21.79 & 0.49 \\
\hline $\mathrm{Al}_{2} \mathrm{O}_{3}$ & 3.75 & 4.19 & 5.05 & 0.27 \\
\hline $\mathrm{Fe}_{2} \mathrm{O}_{3}$ & 2.72 & 3.19 & 3.66 & 0.19 \\
\hline $\mathrm{CaO}$ & 60.40 & 61.70 & 64.38 & 1.01 \\
\hline $\mathrm{SO}_{3}$ & 2.49 & 2.81 & 3.10 & 0.14 \\
\hline $\mathrm{MgO}$ & 2.48 & 3.23 & 3.82 & 0.30 \\
\hline $\mathrm{Na}_{2} \mathrm{O}$ & 0.05 & 0.09 & 0.19 & 0.03 \\
\hline $\mathrm{K}_{2} \mathrm{O}$ & 0.53 & 0.86 & 1.03 & 0.13 \\
\hline Equivalent $\mathrm{Na}_{2} \mathrm{O}$ & 0.44 & 0.66 & 0.81 & 0.10 \\
\hline Free $\mathrm{CaO}$ & 0.67 & 1.28 & 2.10 & 0.32 \\
\hline $\mathrm{Al}_{2} \mathrm{O}_{3} / \mathrm{Fe}_{2} \mathrm{O}_{3}(\mathrm{AM})^{*}$ & 1.20 & 1.31 & 1.41 & 0.23 \\
\hline \multicolumn{5}{|c|}{ Physical properties } \\
\hline Blaine surface area $\left(\mathrm{m}^{2} / \mathrm{kg}\right)$ & 251.00 & 277.84 & 302.00 & 14.90 \\
\hline Initial setting time (min) & 115.00 & 127.65 & 165.00 & 10.02 \\
\hline Final setting time (min) & 175.00 & 198.09 & 240.00 & 15.81 \\
\hline \multicolumn{5}{|c|}{ Bogue's estimates (\%) } \\
\hline $\mathrm{C}_{3} \mathrm{~S}$ & 41.23 & 53.52 & 65.59 & 5.70 \\
\hline $\mathrm{C}_{3} \mathrm{~A}$ & 4.09 & 5.72 & 8.68 & 0.93 \\
\hline $\mathrm{C}_{4} \mathrm{AF}$ & 8.27 & 9.70 & 11.13 & 0.58 \\
\hline $2 \mathrm{C}_{3} \mathrm{~A}+\mathrm{C}_{4} \mathrm{AF}$ & 18.87 & 21.13 & 25.77 & 1.49 \\
\hline
\end{tabular}

* AM = alumina modulus. For Taylor's procedure: $1.0<M A<4.0$

Table III - Specific mass of the cement.

[Tabela III - Massa específica do cimento.]

\begin{tabular}{ccccccc}
\hline & \multicolumn{2}{c}{ Test number } & Average & $\begin{array}{c}\text { Standard } \\
\text { deviation }\end{array}$ \\
\hline Specific mass $\left(\mathrm{kg} / \mathrm{m}^{3}\right)$ & 1 & 2 & 3 & 4 & 13.91 \\
\hline Batch 23 & 3165.31 & 3182.32 & 3148.25 & 3165.38 & 3165.32 & 6.70 \\
Batch 34 & 3145.00 & 3140.49 & 3136.28 & 3129.23 & 3137.75 & \\
\hline \multicolumn{7}{c}{ Average of 34 batches } \\
\hline
\end{tabular}

main oxide phases of the clinker.

The results presented hereafter correspond to the average of 34 batches compared to estimates obtained from Bogue's equations, Taylor's procedure end optical microscopy. According to Taylor's procedure [6], the contents of each oxide must be subtracted from the total impurities present in the starting materials used in the clinker production.

a) Alite substitution $\left(\mathrm{C}_{3} \mathrm{~S}\right)$ :

$\mathrm{Mg}^{2+}: M_{\mathrm{a}}=2 \%$ because the contents of $\mathrm{MgO}>3 \%$; $\mathrm{Fe}^{3+}: F_{\mathrm{a}}=0.33 \cdot 3.19=1.05 \%$, corresponding to contents of $\mathrm{Fe}_{2} \mathrm{O}_{3}<4 \% ; \mathrm{Al}^{3+}: A_{2}=0.09 .4 .19=0.38 \%$ since the contents of $\mathrm{Al}_{2} \mathrm{O}_{3}$ is low; $\mathrm{SO}_{3}: \mathrm{SO}_{3 \mathrm{a}}=0.9 \%$.

The total substitution was $4.33 \%$, which is in good agreement with the usual range of $3-4 \%$ [6]. According to Boykova [6], the total contents of substituent oxides in alite can be estimated by

$$
I_{\mathrm{a}}=0.7 \cdot M_{\mathrm{c}}+2.1=0.7 \cdot 3 \cdot 23+2.1=4.36 \%
$$

where $I_{\mathrm{a}}$ is the total contents of impurities, i.e., substituent oxides in alite, $M_{\mathrm{c}}$ is the amount of crystalline $\mathrm{MgO}$ present in the clinker, which corresponds to the amount of $\mathrm{MgO}$ in 
the chemical analyses. The difference between these two values is $0.03 \%$, thus confirming these results. Finally, subtracting the substituents from the contents of $\mathrm{CaO}$ and $\mathrm{SiO}_{2}$ (Table 1.2, p. 8 in [6]) yields:

$\mathrm{CaO}=73.7-2.0-0.38=71.32 \%, \mathrm{SiO}_{2}=26.3-0.9-1.05$ $=24.35 \%$

b) Belite substitution $\left(\mathrm{C}_{2} \mathrm{~S}\right)$ :

Although the correct approach to determine the substituent values for belite due to impurities has not yet been established, the range of $4 \%$ to $6 \%$ has been commonly observed in Portland clinkers [6]. Furthermore, $\mathrm{SO}_{3}$ rich clinkers, such as in the present case, can be represented by [6]

$\underline{S}_{\mathrm{b}}=1.23 . \mathrm{SO}_{3}+0.24=1.23 \cdot 2.81+0.24=3.7 \%$

where $S_{\mathbf{b}}$ is the total contents of substituent sulfate in belite, and $\mathrm{SO}_{3}$ is the contents of sulfate in the clinker, which corresponds to the value determined by chemical analysis. In addition to sulfates, correlations between the substitution of $\mathrm{MgO}$ in belite and in the clinker were also estimated, yielding $3.23 \%$. Hence, the total contents of substituents were $6.93 \%$. Roughly $2 / 3$ of this value corresponds to $\mathrm{SiO}_{2}$ and $1 / 3$ to $\mathrm{CaO}$. Therefore, according to [6]: $\mathrm{CaO}=65.1$ $(6.93 .1 / 3)=62.79 \% ; \mathrm{SiO}_{2}=34.9-(6.93 .2 / 3)=30.28 \%$.

c) Celite substitution $\left(\mathrm{C}_{3} \mathrm{~A}\right)$ :

$\mathrm{Na}_{2} \mathrm{O}_{\text {equiv. }}=0.66 \%$; total of substituents $=13 \% ; F_{\mathrm{a}}=S i_{\mathrm{a}}=$ $13 / 2-0.66=5.84 \%$

For celite, the total impurities are around $13 \%$, equally shared between $\mathrm{CaO}$ and $\mathrm{Al}_{2} \mathrm{O}_{3}$. Thus $\mathrm{CaO}=62.3-5.84-$ $0.66=55.8 \%, \mathrm{Al}_{2} \mathrm{O}_{3}=37.7-5.84-0.66=31.20 \%$

d) Ferrite substitution $\left(\mathrm{C}_{4} \mathrm{AF}\right)$ :

Although the contents of substituents in ferrite has not yet been precisely established, this value has been estimated to be around $10 \%$, mostly concentrated in $\mathrm{CaO}$ and $\mathrm{Al}_{2} \mathrm{O}_{3}$, except for iron rich cements, where the substituents converged in $\mathrm{Fe}_{2} \mathrm{O}_{3} . \mathrm{CaO}=46.1-2.5=43.60 \% ; \mathrm{Al}_{2} \mathrm{O}_{3}=21$ $-2.5=18.50 \% ; \mathrm{Fe}_{2} \mathrm{O}_{3}=32.9-5.0=27.90 \%$.

Adjusting the coefficients according to the previous substitutions yield

$$
\begin{aligned}
& 0.7132 x_{1}+0.6210 x_{2}+0.5580 x_{3}+0.4360 x_{4}=61.70 \\
& 0.2444 x_{1}+0.3190 x_{2}+0.0370 x_{3}+0.0360 x_{4}=20.64 \\
& 0.0100 x_{1}+0.0210 x_{2}+0.3120 x_{3}+0.1850 x_{4}=4.19 \\
& 0.0070 x_{1}+0.0090 x_{2}+0.0510 x_{3}+0.2790 x_{4}=3.19
\end{aligned}
$$

where the values of $x_{1}, x_{2}, x_{3}$ and $x_{4}$ correspond, respectively, to the contents of $\mathrm{C}_{3} \mathrm{~S}, \mathrm{C}_{2} \mathrm{~S}, \mathrm{C}_{3} \mathrm{~A}$ and $\mathrm{C}_{4} \mathrm{AF}$ of the clinker to be produced. Solving this system, $x_{1}=66.45 \% ; x_{2}=12.21 \%$; $x_{3}=5.52 \%$ and $x_{4}=8.35 \%$.

From these results it can be seen that the calculated values are significantly different than those obtained using Bogue's equations (Table II), whereas the sum of aluminates $(13.88 \%)$ is lower than Bogue's estimates (15.41\%), the sum of silicates $(78.66 \%)$ is higher $(72.33 \%)$. Similar conclusions have been reported $[6,10]$.

The values of specific mass of the main clinker phases, as established by ASTM C 1356 - 96 [4] (Table IV), can be used along with the estimates of $x_{1}$ to $x_{4}$ to calculate the weighted specific mass yielding $63.76+15.24+5.41+8.35$ $+1.28+0.00+(3.23-2.00)=95.27 \%$.

It should be pointed out that the amount of $\mathrm{SO}_{3}$ was fully incorporated to belite as substitutional impurities.

Table IV - Density of the main clinker phases. [Tabela IV-Massa específica das principais fases do clínquer.]

\begin{tabular}{cc}
\hline Clinker's phase & Density $\left(\mathrm{kg} / \mathrm{m}^{3}\right)$ \\
\hline Alite & 3180 \\
Belite & 3310 \\
Aluminate & 3030 \\
Ferrite & 3730 \\
Free CaO & 3350 \\
$\mathrm{SO}_{3}$ & 2660 \\
Periclase & 3580 \\
\hline
\end{tabular}

The specific mass can be calculated from $\rho_{\mathrm{cT}}=(0.6376 .3$ $180.00+0.1524 .3310 .00+0.0541 .3030 .00+0.0835 .3$ $730.00+0.0128 .3350 .00+0.0000 .2660 .00+0.0123 .3$ $580.00) / 0.9527=3247.96 \mathrm{~kg} / \mathrm{m}^{3}$.

Likewise, the specific mass of the clinker can be calculated from the values encountered using Bogue's equations $53.52+$ $18.81+5.72+9.70+1.28+2.81+3.23=95.07 \%$ yielding $\rho_{\mathrm{cB}}=(0.5352 .3180 .00+0.1881 .3310 .00+0.0572 .3030 .00$ $+0.0827 .3730 .00+0.0128 .3350 .00+0.0281 .2660 .00+$ $0.0323 .3580 .00) / 0.9507=3253.32 \mathrm{~kg} / \mathrm{m}^{3}$.

Although it can be seen that these values are more accurate than Taylor's estimates, both correspond to clinkers and therefore, cannot be compared to the value obtained using a Le Chatelier test, i.e. $3151.54 \mathrm{~kg} / \mathrm{m}^{3}$, which correspond to the special class cement itself. Hence, adding $6 \%$ of calcium sulfate to that result yield $\rho_{\text {ст }}=(3247.96 .100 .00+2$ $310.00 .6 .00) / 106.00=3194.87 \mathrm{~kg} / \mathrm{m}^{3}, \rho_{\mathrm{cB}}=(3253.32 .100 .00$ $+2310.00 .6 .00) / 106.00=3199.92 \mathrm{~kg} / \mathrm{m}^{3}$.

The differences between these values and those obtained using a Le Chatelier test are small, i.e. $1.37 \%$ and $1.54 \%$, respectively, However, considering the individual phases, significant discrepancies can be seen (Table V). The sum of the contents of the two major phases is higher when calculated by Taylor's procedure comparing to Bogue's equations, conversely to what was observed for the interstitial phases. Such results are consistently reproduced 
when these procedures are employed. Therefore, the main limitation of Bogue's equations is that they do not take into account impurities of the clinker phases. This not only affects the final results but also and most importantly hinders any prediction as to the behavior of hydrated cement slurries from the actual contents of the individual clinker phases. As a benefit, since the actual contents of the interstitial phases are always lower than Bogue's estimates, the behavior of special class cement slurries will be satisfactory, because it will be based on higher-than-predicted contents of the major phases and, consequently, the formation of $\mathrm{C}-\mathrm{S}-\mathrm{H}$ at the expense of ettringite and monosulfates which do not contribute to the performance of oilwell hardened cement slurries.

The final comparison between Bogue's equations and Taylor's procedure was carried out by reflected light optical microscopy. An image of the special class clinker cement can be seen in Fig. 1. Three samples were photographed and had their phases quantitatively analyzed according to ASTM
C $1356-96$ [4]. The results of these analyses in terms of volumetric fractions and in terms of mass $\%$ are shown in Table VI. Finally, the overall results obtained by Bogue's equations, Taylor's procedure and optical microscopy are merged in Table VII.

As it can be seen from Table VII, the composition of the clinker calculated by Taylor's procedure is closer to that estimated by optical microscopy. Therefore, this procedure is recommended to assess the contents of the major crystalline phases of the Special Class Cement instead of Bogue's equations. An important point is observed considering the differences of up to $10.24 \%$ (63.76\% against $53.52 \%)$ observed for $\mathrm{C}_{3} \mathrm{~S}$. The American Petroleum Institute (API) recommends that the contents of $\mathrm{C}_{3} \mathrm{~S}$ for class $\mathrm{G}$ cements should no exceed $58 \%$. Although this limit was established by and fulfills Bogue's equations (53.53\%), it does not comply with Taylor's procedure $(63.76 \%)$. Higher contents of $\mathrm{C}_{3} \mathrm{~S}$ are not essentially deleterious, as it is responsible for the mechanical strength of hardened slurries. On the other

Table V - Composition of Special Class clinker. [Tabela V - Composição do clínquer da Classe Especial.]

\begin{tabular}{ccccccc}
\hline & \multicolumn{7}{c}{ Crystalline phase (\%) } \\
\hline Method & $\mathrm{C}_{3} \mathrm{~S}$ & $\mathrm{C}_{2} \mathrm{~S}$ & $\begin{array}{c}\text { Sum: } \\
\mathrm{C}_{3} \mathrm{~S}+\mathrm{C}_{2} \mathrm{~S}\end{array}$ & $\mathrm{C}_{3} \mathrm{~A}$ & $\mathrm{C}_{4} \mathrm{AF}$ & Sum: \\
& & & & & $\mathrm{C}_{3} \mathrm{~A}+\mathrm{C}_{4} \mathrm{AF}$ \\
\hline Bogue's equations & 53.52 & 18.81 & 72.33 & 5.72 & 9.70 & 15.42 \\
Taylor's procedure & 63.76 & 15.24 & 79.00 & 5.41 & 8.35 & 13.76 \\
Difference & -10.24 & 3.57 & -6.67 & 0.31 & 1.35 & 1.66 \\
\hline
\end{tabular}

Table VI - Number of points counted and volume fraction of clinker in terms of mass fraction. [Tabela VI - Contagem dos pontos e fração volumétrica do clínquer em relação à massa.]

\begin{tabular}{|c|c|c|c|c|c|c|c|c|}
\hline \multirow[t]{2}{*}{ Phase } & \multicolumn{2}{|c|}{ Sample 1} & \multicolumn{2}{|c|}{ Sample 2} & \multicolumn{2}{|c|}{ Sample 3} & \multicolumn{2}{|c|}{ Average } \\
\hline & points & $\%$ & points & $\%$ & Points & $\%$ & Points & $\%$ \\
\hline $\mathrm{C}_{3} \mathrm{~S}$ & 2235 & 57.48 & 2266 & 58.28 & 2277 & 58.56 & 2259 & 58.11 \\
\hline $\mathrm{C}_{2} \mathrm{~S}$ & 487 & 12.53 & 466 & 11.99 & 499 & 12.83 & 484 & 12.45 \\
\hline $\mathrm{C}_{3} \mathrm{~A}$ & 189 & 4.86 & 177 & 4.55 & 181 & 4.66 & 182 & 4.69 \\
\hline $\mathrm{C}_{4} \mathrm{AF}$ & 239 & 6.15 & 209 & 5.38 & 241 & 6.20 & 230 & 5.91 \\
\hline Other phases & 738 & 18.98 & 770 & 19.80 & 690 & 17.75 & 733 & 18.84 \\
\hline Total & 3888 & 100.00 & 3888 & 100.00 & 3888 & 100.00 & 3888 & 100.00 \\
\hline Phase & $\begin{array}{c}\text { Percentage } \\
{[\%]}\end{array}$ & & $\begin{array}{l}\text { Densit } \\
{\left[\mathrm{kg} / \mathrm{m}^{3}\right.}\end{array}$ & & $\begin{array}{l}\text { Pro } \\
{[\mathrm{kg}}\end{array}$ & & & \\
\hline $\mathrm{C}_{3} \mathrm{~S}$ & 58.11 & & 3180 & & 184 & & & \\
\hline $\mathrm{C}_{2} \mathrm{~S}$ & 12.45 & & 3310 & & & & & \\
\hline $\mathrm{C}_{3} \mathrm{~A}$ & 5.39 & & 3030 & & & & & \\
\hline \multirow[t]{2}{*}{$\mathrm{C}_{4} \mathrm{AF}$} & 4.69 & & 3730 & & & & & \\
\hline & & & Total & & 262 & & & \\
\hline
\end{tabular}


Table VII - Composition of Special Class clinker.

[Tabela VII - Composição do clínquer da Classe Especial.]

Crystalline phase (\%)

\begin{tabular}{ccccccc}
\hline Procedure & $\mathrm{C}_{3} \mathrm{~S}$ & $\mathrm{C}_{2} \mathrm{~S}$ & $\begin{array}{c}\text { Sum: } \\
\mathrm{C}_{3} \mathrm{~S}+\mathrm{C}_{2} \mathrm{~S}\end{array}$ & $\mathrm{C}_{3} \mathrm{~A}$ & $\mathrm{C}_{4} \mathrm{AF}$ & $\begin{array}{c}\text { Sum: } \\
\mathrm{C}_{3} \mathrm{~A}+\mathrm{C}_{4} \mathrm{AF}\end{array}$ \\
\hline Bogue's Equation (BE) & 53.52 & 18.81 & 72.33 & 5.72 & 9.70 & 15.42 \\
Taylor's Procedure (TP) & 63.76 & 15.24 & 79.00 & 5.41 & 8.35 & 13.76 \\
Optical Microscopy (OM) & 70.47 & 15.71 & 86.18 & 5.42 & 8.40 & 13.82 \\
Difference between BE and OM & 16.95 & 3.10 & 13.85 & 0.30 & 1.30 & 1.60 \\
Difference between TP and OM & 6.71 & 0.47 & 7.18 & 0.01 & 0.05 & 0.06 \\
\hline
\end{tabular}

hand, API guidelines do not specify limits for the presence of $\mathrm{C}_{2} \mathrm{~S}$. The hydration of $\mathrm{C}_{2} \mathrm{~S}$ results in the strongest individual component of hardened cement slurries [5, 14, 15], since its specific mass and compacity are higher than those of $\mathrm{C}_{3} \mathrm{~S}[6]$. Moreover, its hydration results in higher contents of C-S-H compared to the hydration of $\mathrm{C}_{3} \mathrm{~S}$ [5]. The excess of $\mathrm{C}_{3} \mathrm{~S}$ usually implies in the reduction of $\mathrm{C}_{2} \mathrm{~S}$ and, therefore, in the decrease of mechanical strength. Conversely, high contents of $\mathrm{C}_{3} \mathrm{~S}$ also involve excess of less desirable phases such as $\mathrm{C}_{3} \mathrm{~A}$ and $\mathrm{C}_{4} \mathrm{AF}$. In summary, the guidelines for oilwell cements should establish a limit for $\mathrm{C}_{2} \mathrm{~S}$, in order to assure the expected performance of this material.

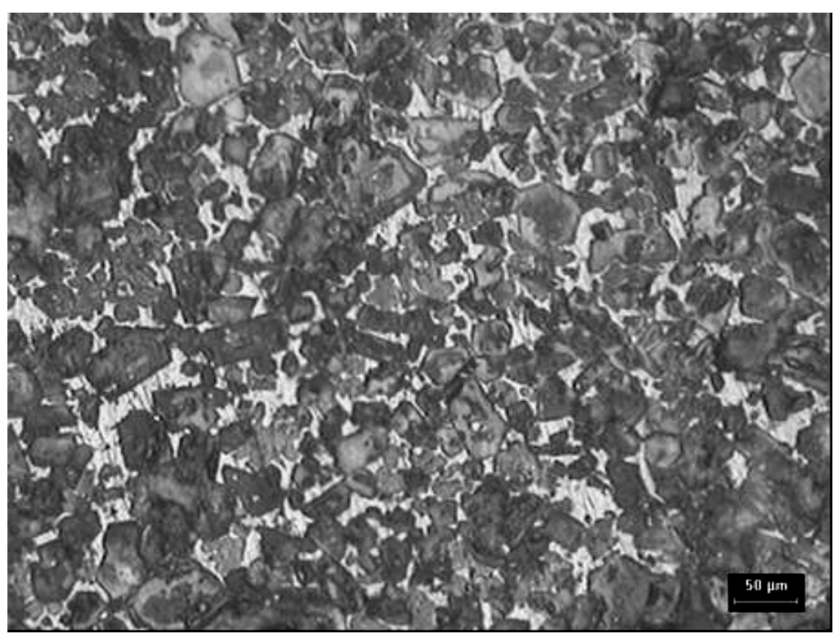

Figure 1: Optical microscopy micrograph of Special Class Portland Cement.

[Figura 1: Micrografia obtida por microscopia óptica do Cimento Portland Classe Especial.]

\section{CONCLUSIONS}

The quantitative crystalline composition of a cement clinker can be determined following either Bogue's equations or Taylor's procedure. The latter approach is more precise and adequate for oilwell cement, since slight variations in the composition of its clinker can result in property changes deleterious to its intended application. In particular, the specific mass of Special Class Portland cement should be determined by Taylor's procedure, since it yields accurate results especially for the major clinker compounds. Taylor's procedure also results in more precise contents of $\mathrm{C}_{3} \mathrm{~S}, \mathrm{C}_{2} \mathrm{~S}$, and mainly $\mathrm{C}_{3} \mathrm{~A}$ and $\mathrm{C}_{4} \mathrm{AF}$ comparing to Bogue's equations. In addition, microscopic images of the oilwell cement should also be periodically analyzed to adjust Taylor's parameters according to the actual production system of each oilwell cement company. Therefore, Taylor's procedure consists in a useful tool to determine the composition of oilwell cement clinker, contributing to the maintenance of rigorous quality control necessary for oil field applications.

\section{REFERENCES}

[1] R. N. Swamy, N. P. Barbosa, "Desenvolvimento de concretos duráveis e resistentes através do uso de cinzas volantes e escória de alto forno moída", J. Pessoa, SCIENTEC/LABEME/CT/UFPB (1998).

[2] Information on http://www.ciks.cbt.nist.gov/garbocz/ cell1994/cellauto.htm.

[3] A. C. Morelli, "O efeito de adições minerais nas propriedades mecânicas de pastas de cimento Portland reforçadas com fibras de polipropileno", Dr. Thesis, UFSCar, S. Carlos, SP, Brazil (2001).

[4] American Society for Testing and Materials, "Standard Test Method for Quantitative Determination of Phases in Portland Cement Clinker by Microscopical Point-Count Procedure 1", ASTM, Philadelphia, USA, C 1356 - 96 C 1356 - 96 (2001).

[5] P. K. Mehta, P. J. M. Monteiro, “Concrete: microstructure, properties and materials", McGraw-Hill Professional, New York, USA (2005).

[6] H. F. W. Taylor "Cement Chemistry", Thomas Telford, New York, USA (2003).

[7] C. F. Gomes, "Argilas: o que são e para que servem", Fund. Calouste Gulbenkian, Lisbon, Portugal (1988).

[8] Y. Kihara, J. K. Shukuzawa, V. A. Zampieri "Estudo mineralógico de pozolanas de cinzas volantes por difratometria de raios X", $27^{\text {th }}$ Cong. Bras. Ceram., S. Paulo, SP, Brazil (1983).

[9] L. R. V. Pietroluongo, M. M. Veiga "Análise quantitativa de minerais por difração de raios-X", $26^{\text {th }}$ Cong. Bras. Ceram., Recife, PE, Brazil (1982).

[10] NISTIR 5755, "Guide for X-ray powder diffraction 
analysis of Portland cement and clinker", National Institute of Standards and Technology, Gaithersburg, USA (1996).

[11] Ass. Bras. Cim. Portland, "Estudo quantitativo do clínquer Portland", Report, Brazil.

[12] E. B. Nelson, "Well Cementing", Dowell Schlumberger Educational Services, Houston, USA (1990).

[13] American Petroleum Institute, "Recommended Practice for testing Oil-Well Cements and Cement Additives", API SPEC 10 (2004).
[14] P. C. Hewlett, "Lea's Chemistry of Cement and Concrete", Elsevier/Butterworth-Heinemann, Burlington, USA (2004).

[15] J. J. Thomas, D. Rothstein, H. M. Jennings, B. J. Christensen, "Effect of hydration temperature on the solubility behaviour of Ca-, S-, Al-, and Si-bearing solid phases in Portland cement pastes", Cement Concrete Res. 33 (2003) 2037-2047.

(Rec. 18/02/2010, Ac. 12/03/2010) 